\title{
PENERAPAN KETENTUAN DALAM PRAKTIK SITA JAMINAN ATAS SAHAM GUNA MEMPEROLEH KEPASTIAN HUKUM
}

\author{
Adelia Audiana Gerchikova ${ }^{1}$, Anita Afriana ${ }^{2}$, Sherly Ayuna ${ }^{3}$
}

\begin{abstract}
This research is intended to assert the legal basis for shares guarantee seizure implementation, and execution mechanism towards Court Judgement of Permanent Legal Force, based on positive laws, which should be enforced as an actual legal basis in order to achieve legal certainty as a practice of Shares Guarantee Seizure implementation. The research is conducted through normative juridical method approach The results that shown, firstly, the actual legal basis for the efforts of Shares Guarantee Seizure is contained in article 227 section (1) of HIR in conjunction with Article 511 of The Indonesian Civil Code, as long as its implementation fulfills the basic requirements. Secondly, there are several distinct in the execution mechanisms of Shares Guarantee Seizure towards limited companies.
\end{abstract}

Keywords : Execution, Legal Certainty, Stock, Shares Guarantee Seizure.

\begin{abstract}
Abstrak
Penelitian ini dimaksudkan untuk menegaskan dasar hukum penyitaan jaminan saham dan mekanisme pelaksanaan berdasarkan pada hukum positif yang harus ditegakkan sebagai dasar hukum aktual untuk mencapai kepastian. Penelitian ini dilakukan melalui pendekatan metode yuridis normatif. Hasil pelitian menunjukkan, Pertama, dasar hukum aktual untuk upaya Penyitaan Jaminan Saham tercantum dalam pasal 227 ayat (1) HIR bersamaan dengan Pasal 511 KUH Perdata Indonesia, selama implementasinya memenuhi persyaratan dasar. Kedua, ada beberapa perbedaan dalam mekanisme pelaksanaan Penyitaan Jaminan Saham terhadap perusahaan terbatas.
\end{abstract}

Kata Kunci : Eksekusi, Kepastian Hukum, Saham, Penyitaan Jaminan Saham

\section{A. Latar Belakang}

Hukum Acara Perdata sebagai hukum perdata formiil merupakan peraturan hukum yang mengatur bagaimana caranya menjamin hukum perdata materiil dengan perantaraan hakim. Dengan demikian, dalam hukum acara perdata telah diatur ketentuan terkait penyelesaian perkara salah satunya prosedur beracara di pengadilan. Salah satu sumber hukum acara perdata adalah Herzien Inlandsch Reglement (HIR) yang merupakan produk hukum masa hindia belanda, dan hingga saat ini memiliki peranan dimana ketentuan-ketentuan umum yang mengatur mengenai proses beracara

\footnotetext{
${ }^{1}$ Fakultas Hukum Universitas Padjajaran, agerchikova@yahoo.com

${ }^{2}$ Dosen Fakultas Hukum Universitas Padjajaran, anita.afriana@unpad.ac.id

${ }^{3}$ Dosen Fakultas Hukum Universitas Padjajaran, sherly.ayunaputri@yahoo.com
} 
perdata masih diatur dalam HIR ini. Hukum positif Indonesia telah mengatur perihal upaya hukum sita jaminan guna mencegah pengalihan harta kekayaan yang dimilikinya ${ }^{4}$ dan bertujuan agar mampu menjamin gugatan Penggugat tidak hampa (illusioner) saat putusan telah berkekuatan hukum tetap, serta menjaga kepastian objek eksekusi, dengan cara melakukan penyitaan terhadap barang milik Tergugat, baik bergerak maupun tidak bergerak.

Persoalan sita jaminan tidak terlepas dari permasalahan objek atau benda yang dimintakan, mengingat terdapat ketentuan-ketentuan yang membatasi untuk dilakukan sita atasnya, salah satunya ialah saham. Definisi saham sendiri ialah modal dasar Perseroan Terbatas yang memiliki nilai nominal tertentu. ${ }^{5}$ Saham tersebut sebagai suatu tanda masuk ikut serta dalam modal Perseroan yang pembagian modal Perseroan dalam saham-saham tersebut diatur dalam Anggaran Dasar. ${ }^{6}$

Saham merupakan salah satu benda yang dikualifikasikan sebagai benda bergerak yang tidak berwujud, hal ini diatur dalam Pasal 511 KUHPerdata jo. Pasal 503 KUHPerdata. ${ }^{7}$ Saham dapat dijadikan sebagai objek sita jaminan dengan syarat yang telah diatur dalam Pasal 227 ayat (1) HIR dimana sita jaminan dapat dilakukan dengan dasar adanya sangkaan yang beralasan bahwa saham tersebut akan digelapkan atau dipindahtangankan oleh Tergugat. Akan tetapi, permasalahan muncul ketika terdapat pengaturan atau pedoman yang bertentangan dengan pelaksanaan sita jaminan terhadap saham, yaitu Buku II Pedoman Teknis Administrasi dan Teknis Peradilan Perdata Umum yang diberlakukan berdasarkan Keputusan Ketua Mahkamah Agung Nomor KMA/032/SK/IV/2006. Dalam huruf Y angka 11 pedoman tersebut mengatur bahwa Hakim tidak melakukan sita jaminan atas saham. Pertentangan ini memunculkan ketidakpastian hukum bagi Hakim saat menetapkan suatu sita jaminan dengan objek saham. Ketidakpastian karena ketidakseragaman atas suatu aturan terkait sita jaminan saham ini berdampak pada praktik pelaksanaannya yakni inkonsistensi hakim di pengadilan karena kesulitan dalam mengabulkan sita jaminan yang objeknya berupa saham, sehingga menimbulkan ambiguitas sistem peradilan nasional.

Apabila dilihat dari sudut pandang para hakim, sebagaimana diketahui hakim merupakan pengambil keputusan dalam sengketa yang ada, sehingga berkembang suatu pendapat yang dibuktikan dengan dikeluarkannya hasil Rakernas antara

\footnotetext{
${ }^{4}$ Retnowulan Sutantio dan Iskandar Oeripkartawinata, 2009, Hukum Acara Perdata dalam Teori dan Praktek, Mandar Maju, Bandung, hlm. 97-98.

${ }^{5}$ Man S. Sastrawidjaja dan Rai Mantili, 2008, Perseroan Terbatas Menurut Tiga UndangUndang, Alumni, Bandung, hlm. 14.

${ }^{6}$ C.S.T. Kansil dan Christine S.T. Kansil, 2005, Hukum Perusahaan Indonesia (Aspek Hukum dalam Ekonomi), PT. Pradnya Paramita, Jakarta, hlm. 100.

${ }^{7}$ Djaja S. Meliala, 2015, Perkembangan Hukum Perdata Tentang Benda dan Hukum Perikatan, Nuansa Aulia, Bandung, hlm. 4-6.

7 John Ibrahim, 2013, Teori dan Metodologi Penelitian Hukum Normatif. Bayumedia Publishing, Malang, hlm. 295.
} 
Mahkamah Agung RI dan para Ketua Pengadilan di seluruh lingkup peradilan yang secara tidak langsung membatasi gerak para hakim untuk dapat mengambil suatu keputusan berupa penyitaan dan pelaksanaan sita jaminan atas saham. Dalam Rakernas tersebut dijelaskan bahwa, suatu objek sita baru dapat disita apabila jelas mengenai barang apa yang hendak disita serta harus menyebutkan secara rinci identitas barang tersebut baik nama pemegangnya, jumlahnya dan tempat terdaftarnya. Dalam artian, maka penetapan sita jaminan atas saham harus memerinci identitas pemilik saham, nomor seri, harga atau nilai yang tercantum dalam saham, kapan saham diperoleh, serta jumlah saham yang akan disita.

Mengingat kecenderungan yang berkembang di dunia peradilan bahwa pengadilan pada umumnya akan menolak permohonan sita jaminan atas saham apabila dalam permintaan sita tersebut tidak menyebut secara jelas identitasnya karena dianggap merupakan permintaan yang kabur objeknya, sehingga tidak mungkin diletakkan sita atasnya, sedangkan di sisi lain, diperkuat dengan adanya alasan mengapa hakim tidak diperbolehkan melakukan sita jaminan atas saham dalam Buku II Mahkamah Agung. Kemudian, permasalahan lain yang muncul dalam praktik pelaksanaan sita jaminan itu sendiri terletak pada proses eksekusi sita jaminan terhadap saham apabila dikabulkan oleh hakim.

Judul dan pembahasan pada artikel ini merupakan karya ilmiah yang memiliki unsur pembaharuan, sehingga merupakan karya ilmiah yang orisinil atau berbeda dengan karya tulis ilmiah yang ada sebelumnya. Sebagai perbandingan, adapun karya ilmiah terkait dengan karya tulis ilmiah penulis yang sekiranya menyerupai tulisan ini, yaitu Jurnal Hukum Mimbar Justitia dari Tumpal Napitupulu, pada tahun 2017, dengan judul: "Pembatasan Kewenangan Hakim untuk tidak melakukan Sita Jaminan atas Saham Dikaitkan dengan Buku Pedoman Teknis Administrasi dan Teknis Perdata Umum". Pembahasan dalam jurnal tersebut, lebih menekankan kepada pengkajian kewenangan yang dimiliki Hakim agar sesuai dengan tugas dan wewenangnya untuk menjaga dan menegakkan kehormatan serta etika perilaku Hakim, dimana hakim harus taat pada Buku Pedoman tersebut, dengan mengkaji dari segi sosiologis dan segi pada teori pedoman perilaku hakim agar Hakim tetap menaati kode etik yang ada. ${ }^{8}$

Berdasarkan uraian tersebut, terdapat perbedaan karya ilmiah yang ditulis oleh penulis dengan karya ilmiah lainnya. Keunggulan karya ilmiah penulis dari penelitian lainnya adalah pada karya ilmiah ini, penulis membahas dan menganalisis terlebih dahulu kedudukan hukum HIR dan Buku II Pedoman Teknis Administrasi dan Teknis Peradilan Perdata Umum dalam teori hierarki perundang-undangan berdasarkan hukum positif yang seharusnya diberlakukan terhadap upaya sita jaminan atas saham, lalu diikuti dengan menganalisis kedudukan Rakernas, serta mengkaji mekanisme

8 Tumpal Napitupulu, "Pembatasan Kewenangan Hakim untuk tidak melakukan Sita Jaminan atas Saham Dikaitkan dengan Buku Pedoman Teknis Administrasi dan Teknis Perdata Umum”, Jurnal Mimbar Justitia, (Vol 3 Nomor 1, 2017), hlm. 55-74. 
eksekusi sita jaminan saham dalam kerangka hukum acara perdata, sehingga praktik eksekusi tersebut dapat memperoleh kepastian hukum sesuai dengan cita-cita negara Indonesia sebagai negara hukum.

\section{B. Rumusan Masalah}

Adapun permasalahan yang akan dikaji dalam penulisan ini adalah:

1. Bagaimanakah eksistensi pengaturan mengenai sita jaminan atas saham ditinjau dari Herzien Inlandsch Reglement (HIR) dan Buku II Pedoman Teknis Administrasi dan Teknis Peradilan Perdata Umum?

2. Bagaimanakah mekanisme dalam eksekusi sita jaminan terhadap saham di Indonesia dalam rangka penyelesaian sengketa yang berkepastian hukum berdasarkan hukum acara perdata?

\section{Metode Penelitian}

Metode penelitian yang digunakan dalam penelitian ini adalah pendekatan yuridis normatif, yaitu berdasarkan pada kaidah hukum dalam hukum positif ${ }^{9}$ Dengan demikian, teknik pengumpulan data dilakukan dengan studi kepustakaan (library research) dengan mengedepankan data sekunder menggunakan bahan hukum primer, sekunder dan tersier, serta didukung dengan studi lapangan melalui hasil wawancara kepada sejumlah Hakim untuk memperoleh data-data yang bersifat primer. Spesifikasi penelitian yang digunakan adalah deskriptif analitis yang selanjutnya dianalisis secara yuridis kualitatif.

\section{Hasil Penelitian dan Pembahasan}

\section{Eksistensi Pengaturan Sita Jaminan atas Saham dalam Herzien Inlandsch Reglement (HIR) dan Buku II Pedoman Teknis Administrasi dan Teknis Peradilan Perdata Umum}

Sita jaminan merupakan salah satu upaya untuk menjamin hak yang dilakukan dengan menyita benda-benda bergerak maupun tidak bergerak milik Tergugat, agar suatu putusan yang memenangkan pihak pemohon sita tidaklah illusoir. ${ }^{10}$ Sita jaminan sebagai suatu upaya untuk menjamin hak, pada dasarnya merupakan bagian dari hukum formil (hukum acara) yang menjamin terlaksananya hukum materiil melalui mekanisme persidangan. Ketentuan-ketentuan yang mengatur hukum acara perdata di Indonesia pada dasarnya tidak diatur dalam suatu wet atau

9 John Ibrahim, 2013, Teori dan Metodologi Penelitian Hukum Normatif, Bayumedia Publishing, Malang, hlm. 295.

${ }^{10}$ Sudikno Mertokusumo, 2005, Hukum Acara Perdata, Liberty, Yogyakarta, hlm. 92. 
undang-undang dalam arti formil, ${ }^{11}$ namun masih bergantung pada produk hukum hasil jajahan kolonialisme, yakni Herzien Inlandsch Reglement (HIR). Status dari Herzien Inlandsch Reglement (HIR) sendiri setara dengan undang-undang. ${ }^{12}$ Pandangan ini dapat disimpulkan bahwa Herzien Inlandsch Reglement (HIR) bukan merupakan undang-undang (wet), namun merupakan produk hukum yang setara dengan undang-undang. Hal tersebut ditunjukkan apabila dikaitkan dengan hierarki peraturan perundang-undangan di Indonesia, sebagaimana dapat diketahui dalam Pasal 7 ayat (1) UU No. 12 Tahun 2011 tentang Pembentukan Peraturan Perundang-undangan, merupakan peraturan yang setara pada jenjang undang-undang. ${ }^{13}$

Mengingat sita jaminan sebagai bagian dari hukum acara perdata, maka pengaturan terhadap sita jaminan tersebut juga tunduk pada ketentuan-ketentuan terkait mekanisme pembentukan hukum acara berdasarkan hukum positif di Indonesia. Pengaturan terkait pembentukan hukum acara di Indonesia berdasarkan peraturan perundang-undangan, pertama kali dapat ditemukan pada ketentuan Pasal 24A ayat (5) Undang-Undang Dasar 1945. Pasal tersebut menjelaskan bahwa hukum acara Mahkamah Agung dan badan peradilan dibawahnya diatur oleh undang-undang. ${ }^{14}$ Undang-undang dalam pasal tersebut, ditafsirkan sebagai undang-undang dalam arti formil (wet in formele zin), ${ }^{15}$ yaitu undang-undang yang dibentuk oleh pembentuk undang-undang. Hal ini kemudian dapat dimengerti kaitannya dengan pembentukan UU No. 14 Tahun 1985 tentang Mahkamah Agung.

Dapat dipahami bahwa UU No. 14 Tahun 1985 tentang Mahkamah Agung sebagaima telah diubah dengan UU No. 3 Tahun 2009 tentang perubahan Kedua atas UU No.14 Tahun 1985 tentang Mahkamah Agung (Selanjutnya disebut UU MA) sebagai perwujudan dari ketentuan Pasal 24A ayat (5) UUD 1945 memuat pengaturan-pengaturan terkait hukum acara. Hal ini mengingat Pasal 24A ayat (5) UUD 1945 mengatur bahwa hukum acara diatur dengan undang-undang, tidak terkecuali Hukum Acara Perdata.

Pembentuk undang-undang memberikan kewenangan bagi Mahkamah Agung untuk mengatur lebih lanjut hukum acara Mahkamah Agung, sebagaimana diatur pada Pasal 79 UU MA, yang menjelaskan bahwa dalam satu kondisi Mahkamah Agung diberikan kewenangan untuk membentuk peraturan yang secara keseluruhan merupakan bagian dari hukum acaranya, ketika terjadi kekurangan

${ }^{11}$ Maria Farida Indrati, 2007, Ilmu Perundang-Undangan: Jenis, Fungsi, dan Materi Muatan, Kanisius, Yogyakarta, hlm. 54.

${ }^{12}$ Ibid.

13 Pasal 7 ayat (1) Undang-Undang No. 12 Tahun 2011 tentang Pembentukan Peraturan Perundang-undangan.

14 Pasal 24A ayat (5) Undang-Undang Dasar 1945.

${ }^{15}$ Ibid, hlm. 52. 
atau kekosongan hukum. ${ }^{16}$ Hal ini juga berlaku dalam hal pembentukan Buku II Pedoman Teknis Administrasi dan Teknis Peradilan Perdata yang merupakan interne regeling hasil kewenangan Mahkamah Agung dalam menjalankan fungsi pengaturan atau regelende functie. Dengan demikian, regelende functie Mahkamah Agung dalam pembentukan Buku II Pedoman Teknis Administrasi dan Teknis Peradilan Perdata harus dimengerti ketika hukum acara yang diatur dalam buku pedoman tersebut, dibentuk untuk melengkapi kekurangan atau mengisi kekosongan hukum.

Sita jaminan sebagai bagian dari upaya dalam hukum formil yang disediakan dalam proses beracara merupakan pula bagian dari pengaturan dalam Buku II Pedoman Teknis Administrasi dan Teknis Peradilan Perdata. Hal tersebut dapat ditemukan pada bagian teknis peradilan, huruf Y (halaman 82) Buku II Pedoman Teknis Administrasi dan Teknis Peradilan Perdata. Akan tetapi, dalam pengaturan tersebut, terdapat ketentuan bahwa Hakim tidak melakukan sita jaminan atas saham. Ketentuan pada angka 11, huruf Y Buku II mengenai sita jaminan tersebut seharusnya dilihat sebagai pengaturan yang menggantikan pengaturan hukum acara yang sudah ada dan bukan merupakan regelende functie dari Pasal 79 UU MA, mengingat tidak terjadinya kekosongan hukum ketika berbicara mengenai sita jaminan atas objek saham yang telah diatur dalam ketentuan Pasal 227 ayat (1) HIR jo. Pasal 511 KUHPerdata. Hal ini mengingat Pasal 227 ayat (1) HIR memungkinkan dilakukannya sita jaminan atas benda bergerak, yang mana saham sendiri dikualifikasikan sebagai benda bergerak tidak berwujud. Dengan demikian, jelas terlihat bahwa ketentuan terkait sita jaminan atas saham, bukanlah merupakan pengaturan yang kosong, atau belum diatur, melainkan telah diatur berdasarkan HIR.

Kekurangan atau kekosongan hukum menjadi indikator dari dilaksanakannya regelende functie Mahkamah Agung dalam membentuk hukum acara lanjutan guna melengkapi hukum yang telah ada dan bukan membentuk suatu kaidah hukum yang menggantikan kaidah hukum lain. Hal ini berkaitan pula dengan Pasal 79 UU MA yang menyatakan bahwa peraturan yang dibentuk berdasarkan atribusi dalam pasal tersebut dibedakan dengan peraturan yang disusun oleh pembentuk undang-undang. Penyelenggaraan peradilan yang dimaksud juga dijelaskan sebagai bagian dari hukum acara secara keseluruhan. Dengan demikian, kedudukan Buku II Pedoman Teknis Administrasi dan Teknis Peradilan Perdata sebagai peraturan hasil bentukan Mahkamah Agung tidak berada pada posisi yang setara dengan undang-undang dan hanya merupakan bagian dari hukum acara.

Sita jaminan yang diatur dalam ketentuan Pasal 227 ayat (1) HIR jo. Pasal 511 KUHPerdata seharusnya dilihat sebagai suatu peraturan hukum acara yang sudah

\footnotetext{
${ }^{16}$ Pasal 79 Undang-Undang Nomor 14 Tahun 1985 tentang Mahkamah Agung.
} 
diberlakukan sebelumnya, sehingga bukan menjadi hukum acara yang diatur lagi berdasarkan kewenangan Mahkamah Agung. Hal ini mengingat pula bahwa HIR merupakan peraturan masa kolonial yang diberlakukan berdasarkan Pasal I Aturan Peralihan UUD 1945, sehingga kekuatan berlakunya hingga pada masa sekarang sepanjang belum diadakannya pengaturan yang baru. Dalam jenjang norma peraturan perundang-undangan sendiri, Herzien Inlandsch Reglement memiliki posisi yang setara dengan undang-undang. ${ }^{17}$

Buku II Pedoman Teknis Administrasi dan Teknis Peradilan Perdata Umum edisi 2007 sekilas terlihat sebagai pengaturan yang lebih khusus terhadap ketentuan sita jaminan dalam Herzien Inlandsch Reglement. Meskipun begitu, Buku II Pedoman Teknis Administrasi dan Teknis Peradilan Perdata Umum tidak dapat dinyatakan sebagai pengaturan yang lebih khusus daripada ketentuan dalam Herzien Inlandsch Reglement, mengingat asas lex specialis derogate legi generali diberlakukan saat terdapat dua pengaturan atau lebih dalam hierarki yang sederajat. $^{18}$

Buku II Pedoman Teknis Administrasi dan Teknis Peradilan Perdata Umum, dalam kaitannya dengan teori jenjang norma Hans Kelsen, merupakan peraturan yang diberlakukan berdasarkan atribusi kewenangan dari UU MA tentang Mahkamah Agung, khususnya kewenangan untuk membentuk peraturan. Tujuan atribusi kewenangan ini ialah untuk terselenggaranya peradilan yang lancar, yang mana dapat dimaknai pula tidak tumpang tindih dengan pengaturan lain.

Atribusi kewenangan bagi Mahkamah Agung untuk membentuk hukum acara berdasarkan pada ketentuan Pasal 79 UU MA tentang Mahkamah Agung, yang mana berdasarkan penjelasannya, peraturan yang dibentuk oleh Mahkamah Agung dibentuk untuk mengisi kekosongan hukum. Hal ini jelas berbeda dengan ketentuan terkait sita jaminan atas saham, dimana pengaturannya jelas masih terdapat dalam ketentuan Pasal 227 ayat (1) HIR jo. Pasal 511 KUHPerdata, namun diatur sebaliknya berdasarkan ketentuan dalam Buku II Pedoman Teknis Administrasi dan Teknis Peradilan Perdata Umum.

Sita jaminan atas saham, sebagai suatu hukum acara yang telah diatur berdasarkan Pasal 227 ayat (1) HIR jo. Pasal 511 KUHPerdata, merupakan pengaturan yang diberlakukan sebagai hukum positif. Sementara itu, Buku II Pedoman Teknis Administrasi dan Teknis Peradilan Perdata Umum, sebagai peraturan yang dibentuk berdasarkan atribusi kewenangan bagi Mahkamah Agung, sebagaimana ketentuan Pasal 79 UU No. 14 Tahun 1985 tentang Mahkamah Agung, tidaklah dapat menggantikan ketentuan pengaturan terkait sita

17 Ibid.

18 Harmonisasi Peraturan Perundang-Undangan, http://ditjenpp.kemenkumham.go.id/htndan-puu/421-harmonisasi-peraturan-perundang-undangan.html, diakses pada tanggal 5 Januari 2020. 
jaminan atas saham yang telah diatur dalam Pasal 227 ayat (1) HIR jo. Pasal 511 KUHPerdata.

Ketentuan Pasal 24A ayat (5) UUD 1945 yang dikaitkan dengan Herzien Inlandsch Reglement sebagai hukum acara perdata yang berlaku hingga sekarang, maka terlepas dari problematika-problematika sebagaimana yang telah dijabarkan pada bagian sebelumnya, pengaturan terhadap sita jaminan atas saham seharusnya merujuk pada ketentuan dalam Herzien Inlandsch Reglement (HIR). Dengan demikian, secara kaidah hukum acara perdata, pada dasarnya sita jaminan atas saham dapat dilakukan (Pasal 227 ayat (1) HIR jo. Pasal 511 KUHPerdata), sehingga tidak benar apabila Hakim dalam putusannya menjadikan Buku II sebagai dasar hukum, mengingat Buku II bukanlah sebuah sumber hukum atau produk regulasi.

Berdasarkan hasil analisis terhadap eksistensi pengaturan mengenai sita jaminan terhadap saham dalam Herzien Inlandsch Reglement dan Buku II Pedoman Teknis Administrasi dan Teknis Peradilan Perdata Umum, dikaitkan dengan penafsiran atas kewenangan Mahkamah Agung berdasarkan atribusi Pasal 79 UU MA, dapat disimpulkan bahwa ketentuan yang diberlakukan untuk upaya sita jaminan atas saham ialah ketentuan dalam Herzien Inlandsch Reglement (HIR). Mengingat ketentuan yang diberlakukan terhadap sita jaminan atas saham ialah ketentuan dalam Herzien Inlandsch Reglement, maka disimpulkan bahwa sita jaminan atas saham dapat terlaksanakan atau dapat dimohonkan oleh pihak berperkara sepanjang memenuhi unsur pokok yang telah diatur dalam Pasal 227 HIR.

Unsur pokok yang harus diperhatikan sebagai dasar alasan untuk mengajukan sita jaminan yang diatur dalam Pasal 227 HIR, yaitu mengenai ketentuan yang harus diturut tentang dasar alasan apakah sita jaminan dapat dikabulkan, yaitu:

a. Ada sangka yang beralasan

b. Tergugat mencari akal akan menggelapkan barang atau mencari akal akan mengasingkan barangnya kepada orang lain,

c. Dengan maksud akan menjauhkan barang itu dari haknya penggugat,

d. Dapat dikabulkan selama proses persidangan sedang berjalan (sebelum putusan dijatuhkan), atau sebelum putusan yang menghukumnya belum dapat dilaksanakan karena belum mempunyai kekuatan hukum tetap.

Itulah beberapa unsur pokok yang dapat menjadi dasar alasan untuk dikabulkannya suatu sita jaminan, apabila salah satu unsur pokok tidak terpenuhi, maka Majelis Hakim wajib menolaknya. 


\section{Mekanisme Pelaksanaan Eksekusi Sita Jaminan terhadap Saham dalam Praktik Peradilan guna Memperoleh Kepastian Hukum}

Sita Jaminan sebagai suatu upaya untuk menjamin hak dari pihak Pengugat ketika dimenangkan oleh putusan pengadilan, pada dasarnya merupakan suatu upaya yang sudah dikenal sejak diberlakukannya Herzien Inlandsch Reglement (HIR). Kembali pada bunyi ketentuan dalam Pasal 227 ayat (1) HIR, sita jaminan merupakan upaya menjamin hak dengan melakukan penyitaan (beslag) terhadap barang tetap maupun barang bergerak milik Tergugat. Dalam meletakkan sita jaminan atas barang milik Tergugat tersebut, Majelis Hakim dituntut untuk memperhitungkan setiap barang yang disita kemudian dikaitkan dengan nilai ganti rugi yang dimohonkan oleh Penggugat. Hal ini dilakukan agar penyitaan atas benda bergerak milik Tergugat tidaklah berlebihan.

Ketidakseragaman atas suatu aturan terkait sita jaminan atas saham sebagai dasar pertimbangan Majelis Hakim, memunculkan ketidakpastian hukum bagi Hakim itu sendiri, dimana Majelis Hakim kesulitan untuk mengabulkan penetapan sita jaminan. Seperti yang telah dijelaskan sebelumnya, bahwa pengaturan mengenai sita jaminan telah diatur dalam HIR Pasal 227 ayat (1), dimana sita jaminan dapat dilaksanakan sepanjang syarat sita jaminan yakni "sangkaan yang beralasan bahwa Tergugat akan menggelapkan barang" dapat terbukti. Sehingga ketentuan huruf Y angka II dalam Buku II Pedoman Teknis Administrasi dan Teknis Peradilan Perdata Umum, yang menegaskan bahwa Hakim tidak melakukan sita jaminan atas saham, adalah tidak benar untuk dijadikan sebuah dasar hukum.

Dalam praktik pengadilan, seorang Hakim tidak boleh menjadikan Buku II Pedoman Teknis Administrasi dan Teknis Peradilan Perdata Umum sebagai dasar pertimbangan, seharusnya menggali aturan induknya atau sumber hukum yang sebenarnya, mencari dasar hukum atau peraturan yang menjadi induk dari pada substansi dalam Buku II ini, seperti yang dipaparkan dalam Buku II itu adalah HIR, maka yang seharusnya menjadi dasar pertimbangan suatu putusan sita jaminan saham itu adalah HIR dan bukan Buku II, hanya karena semata-mata tidak ingin terkena sanksi hukum (kode etik) karena tidak mematuhi Buku II. ${ }^{19}$ Praktiknya, Buku II Pedoman Teknis Administrasi dan Teknis Peradilan Perdata Umum hanya bersifat buku bantu untuk para Hakim ketika tidak mengetahui suatu aspek hukum. Oleh karena itu, di dalamnya hanya mengangkat peraturanperaturan yang sesungguhnya yang kemudian disusun menjadi Buku II Pedoman Teknis Administrasi dan Teknis Peradilan Perdata Umum. ${ }^{20}$

19 Wawancara Peneliti dengan Hakim Pengadilan Negeri Kelas IA Khusus Bandung, Pak Mangapul Girsang, pada tanggal 4 Maret 2020, Pukul 14.00 WIB.

20 Wawancara Peneliti dengan Hakim Pengadilan Negeri Kelas IA Khusus Bandung, Pak Mangapul Girsang, pada tanggal 4 Maret 2020, Pukul 14.00 WIB. 
Berbicara mengenai Rakernas, yang mengemukakan bahwa: "Dalam penetapan sita jaminan terhadap barang-barang bergerak harus memerinci identitas dan jumlah barang dalam arti disebut nama pemegangnya, jumlahnya dan tempat terdaftarnya.", Apabila diteliti lebih lanjut dengan melihat dari kedudukan hukumnya, Rakernas memiliki kedudukan yang berada di luar hukum positif yang berlaku di Indonesia, sehingga menjadi pertanyaan apakah Majelis Hakim sebagai pengambil keputusan dapat beracuan kepada Rakernas.

Sebelumnya, perlu dicermati bahwa Rapat Kerja Nasional atau Rakernas menurut Bagir Manan, merupakan sebuah tradisi organisasi dimana dengan adanya Rakernas maka ada sebuah pikiran-pikiran baru, arahan-arahan baru, melakukan evaluasi capaian hasil-hasil yang lalu, menyampaikan pengalaman baru, temuan baru, masalah-masalah baru untuk dirembukkan bersama guna menemukan langkah-langkah selama satu tahun mendatang. Selain itu, Beliau juga menambahkan bahwa penyelenggaraan Rakernas sebagai upaya modernisasi pengadilan yang menjadi suatu keharusan dikarenakan kini peradilan Indonesia berhadapan dengan era modernisasi. ${ }^{21}$

Senada dengan yang diungkapkan oleh Ketua Mahkamah Agung, Hatta Ali yang menyatakan tujuan Rakernas Mahkamah Agung adalah penyamaan persepsi tentang penerapan hukum. ${ }^{22}$ Tujuan Rakernas juga untuk mendiskusikan dan memecahkan permasalahan teknis yuridis menuju pada pemahaman dalam rangka peningkatan profesionalisme Hakim dan kualitas putusan Hakim. Hal ini dikarenakan jajaran pengadilan di berbagai tingkatan, termasuk Mahkamah Agung kerap kali membuat putusan yang saling bertentangan dalam suatu jenis perkara yang memiliki kondisi sama, oleh karena itu harus disamakan persepsinya salah satunya dengan diadakannya Rakernas.

Dapat disimpulkan bahwa Rakernas diadakan untuk melakukan persamaan persepsi pada jajaran pengadilan di berbagai tingkatan, namun bukan berarti Majelis Hakim dapat memutuskan suatu perkara berdasarkan Rakernas, karena keputusan Hakim mengenai suatu perkara haruslah dengan alasan dan menggunakan dasar-dasar yuridis yang jelas seperti yang tercantum dalam Pasal 178 ayat (1) HIR. Alasan-alasan hukum disini berisikan tentang sumber-sumber hukum sebagai dasar alasan yang mengabulkan atau menolak putusan tersebut. Dalam hal ini Rakernas bukan merupakan sumber hukum yang dapat digunakan bagi Hakim dalam memutus suatu perkara karena Rakernas hanyalah sebuah rapat internal dan bukan berupa suatu ilmu pengetahuan yang diakui banyak pihak atau berupa ajaran para ahli dan bukan pula suatu peraturan hukum.

\footnotetext{
${ }^{21}$ Persamaan Persepsi Penerapan Hukum Rakernas, http://www.primaironline.com/berita/detail.php?catid=Peradilan\&artid=rakernas-ma-rekomendasikanpersamaan-persepsi-penerapan-hukum, diakses pada tanggal 3 Januari 2020.

${ }^{22}$ Wawancara Peneliti dengan Hakim Mahkamah Agung, Pak MD. Pasaribu, pada tanggal 14 Maret 2020, pukul 09.00 WIB.
} 
Adapun Hukum Acara Perdata Positif yang dapat digunakan oleh Majelis Hakim salah satunya Putusan Mahkamah Agung RI sebagai yurisprudensi, sedangkan Rakernas hanya sebagai sebuah wadah untuk mendiskusikan dan memecahkan permasalahan yang terjadi dalam pengambilan putusan dimana yang didiskusikan adalah dasar hukum apa yang harus digunakan untuk menghadapi suatu perkara agar Hakim kedepannya dalam membuat putusan terhadap suatu jenis perkara yang memiliki kondisi sama sekali tidak saling bertentangan.

Hakim walaupun hanya secara lisan mengatakan perkara tersebut ditolak karena tidak sejalan dengan Rakernas, namun hal itu tetap tidak dapat dibenarkan untuk menjadikan Rakernas sebagai dasar alasan hukum untuk ditolaknya suatu perkara, karena seharusnya Hakim tidak mengatakan secara lisan tetapi akan lebih baik apabila Majelis Hakim menulis dalam putusannya disertai dengan dasar hukum apa yang mendasari ditolaknya permohonan sita jaminan atas saham tersebut, dikarenakan objek sita jaminan yang dimohonkan tidak disebutkan secara terperinci. Hal seperti ini tentunya hanya akan menimbulkan kesimpangsiuran terhadap proses peradilan.

Kembali pada ketentuan Buku II Pedoman Teknis Administrasi dan Teknis Peradilan Perdata Umum huruf Y angka 11 bahwa: "Hakim tidak melakukan sita jaminan atas saham" dan angka 12 bahwa: "Pemblokiran atas saham dilakukan oleh Bapepam atas permintaan Ketua Pengadilan Tinggi dalam hal ada hubungan dengan perkara." ${ }^{23}$, Berdasarkan hasil analisis, ketentuan tersebut hanya diberlakukan bagi permohonan sita jaminan atas saham-saham milik Perseroan Terbuka (go public) yang berada pada Bursa Efek, dengan pemblokiran efek yang dilakukan oleh OJK dan bukanlah Hakim ${ }^{24}$, sehingga ketentuan tersebut tidak dapat diberlakukan bagi penyitaan saham konvensional atau saham pada Perseroan Tertutup.

Dalam praktiknya, mekanisme eksekusi sita jaminan terhadap saham pada Perseroan Tertutup, tidak terdapat problematika saat pelaksanaannya. Tidak adanya hambatan dalam mekanisme eksekusi sita jaminan saham Perseroan Tertutup dikarenakan penyitaannya bersifat administratif, dimana sifat saham itu tidak berwujud sehingga lebih memiliki makna yuridis. ${ }^{25}$ Saat proses eksekusi, cukup dengan juru sita menyatakan jumlah lembaran saham dan identitas kepemilikannya yang kemudian penetapan sita saham tersebut didaftarkan di Departemen Hukum dan Hak Asasi Manusia atau yang selanjutnya disebut Depkumham.

${ }^{23}$ Buku II Pedoman Teknis Administrasi dan Teknis Peradilan Perdata Umum Edisi 2007, di revisi tahun 2009.

${ }^{24}$ Wawancara Peneliti dengan Hakim Pengadilan Negeri Kelas IA Khusus Jakarta Selatan, Pak Djoko Indiarto, pada tanggal 7 Maret 2020, pukul 08.00 WIB.

${ }^{25}$ Wawancara Peneliti dengan Hakim Pengadilan Negeri Kelas IA Khusus Jakarta Selatan, Pak Djoko Indiarto, pada tanggal 7 Maret 2020, pukul 08.00 WIB. 
Pengalihan saham sendiri diawali dengan perubahan akta pendirian, yang didalamnya terdapat susunan pengurus, anggaran dasar, dan identitas kepemilikan saham, yang didaftarkan di Depkumham, oleh karena itu penyitaan pun dilakukan di Depkumham. Jadi, apabila terdapat transaksi jual-beli saham yang dituangkan dalam akta notaris dalam rangka mengalihkan kepemilikan saham, akta notaris baru tersebut yang juga merupakan perubahan anggaran dasar harus didaftarkan di Depkumham, sehingga langsung terdeteksi jika terdapat perubahan kepemilikan saham.

Berdasarkan pembahasan di atas, dapat diketahui bahwa hambatan dalam mekanisme eksekusi sita jaminan saham hanya terjadi pada penyitaan atas saham go public karena saham-saham tersebut berada pada Bursa Efek. Apabila dikaitkan dengan problematika ketentuan sita jaminan saham dalam Buku II Pedoman Teknis Administrasi dan Teknis Peradilan Perdata Umum angka 11, pada hakikatnya, secara yuridis boleh disita tetapi dalam pelaksanaannya sudah diketahui akan sulit dilaksanakan, bagaimana mendaftarkan ke Depkumham karena tidak diketahuinya seri daripada saham tersebut, oleh karena itu penyitaan tersebut menjadi tidak efektif karena kesulitan mengidentifikasi saham yang berada di Bursa Efek.

Sulitnya mengidentifikasi saham yang berada di Bursa Efek, karena diperlukan adanya kerjasama dengan pihak Bursa Efek untuk mengetahui nomor seri kepemilikan, hal tersebut tidak mudah dan memakan waktu yang lama, karena diperlukan serangkaian izin dari beberapa instansi. Sedangkan, mengenai saham Perseroan Tertutup, hanya melihat pada akta pendiriannya atau perubahan akta pendiriannya, didalamnya tercantum pemilik saham dan jumlah saham, berhubung saham tersebut tidak ada nomor serinya. Begitu dinyatakan jumlah saham yang akan disita, lalu dinyatakan sah dan berharga, maka pihak Pengadilan melalui juru sita langsung mendaftarkan ke Depkumham, agar yang bersangkutan tidak mengalihkan sahamnya, karena pengalihan saham sendiri harus melalui perubahan akta yang didaftarkan di Depkumham.

Jadi, ketentuan dalam Buku II bukan melarang secara mutlak tetapi teknisnya yang sulit dilakukan sehingga tidak memungkinkan untuk dilaksanakan sita atas saham. Harus dipahami pula mengenai syarat dalam Rakernas ini berlaku bagi penyitaan saham go public saja. ${ }^{26}$ Ketika seorang Hakim mengabulkan atau tidak mengabulkannya suatu perkara sita jaminan saham, Hakim tersebut harus memiliki pemikiran bahwa penyitaan tersebut dapat dilaksanakan atau tidak, karena mengalami kesulitan untuk menyimpulkan, maka kecenderungannya menjadi tidak dikabulkan. Hal tersebut dikarenakan alasan yuridis dalam menetapkan penolakan sita, bahwa Pemohon sendiri tidak bisa menjelaskan identitas sahamnya. Dengan tidak diketahuinya identitas saham yang sistemnya

${ }^{26}$ Wawancara Peneliti dengan Hakim Pengadilan Negeri Kelas IA Khusus Bandung, Pak Mangapul Girsang, pada tanggal 4 Maret 2020, Pukul 14.00 WIB. 
dalam suatu bursa, maka tidak mungkin dapat terlaksana. Oleh karena tidak mungkin dapat dilaksanakan, maka tidak berdasar apabila Hakim mengabulkan permohonan sita jaminan atas saham, untuk apa dikabulkan, jika sudah diketahui bahwa eksekusi sita tidak dapat dilaksanakan. ${ }^{27}$

Peluang pengadilan atau Majelis Hakim dalam menolak permohonan sita jaminan saham, terutama jika identitas dari kepemilikan saham tersebut tidak disebutkan dengan jelas meskipun telah ada alasan kuat bagi pihak Penggugat untuk mengajukan permohonan sita jaminan saham, berdampak pada kerugian moril dan materiil bagi pihak yang bersangkutan sehingga berakibat pada ketidakpastian hukum dalam penyelesaian sengketa perdata. ${ }^{28}$ Negara Indonesia sebagai negara hukum memiliki konsekuensi untuk menjadikan hukum berfungsi sebagai pemberi kepastian hukum dan keadilan. ${ }^{29}$

Dalam hal yang berkaitan dengan sita jaminan saham, secara keseluruhan, peraturan diciptakan untuk mencapai kepastian hukum jika melihat kembali pada cita-cita hukum Indonesia. Belum terciptanya produk pengaturan Hukum Acara Perdata merupakan salah satu contoh ketidaksadaran para legislator dalam menciptakan suatu produk hukum agar sesuai dengan yang diharapkan. Terjadi dualisme hukum apabila berbicara mengenai pengaturan hukum acara perdata yang masih diatur dalam HIR dan $\mathrm{RBg}$, karena kedua produk tersebut merupakan peninggalan zaman Belanda dimana dinamika hukum di rezim terciptanya HIR tidak sesuai dengan perkembangan kultur Indonesia.

Oleh karena itu, untuk mencapai suatu kepastian hukum, sudah waktunya menciptakan Hukum Acara Perdata Nasional yang dapat mengakomodir dinamika-dinamika hukum dan seluruh permasalahan perdata di Indonesia, melihat juga bahwa pengaturan sita jaminan khususnya saham dalam HIR masih tidak jelas dan menimbulkan ambiguitas sistem peradilan nasional. Jika sudah tercipta dalam suatu produk perundang-undangan, maka akan tercipta kepastian hukum dalam praktik pelaksanaan sita jaminan atas saham dalam rangka penyelesaian sengketa hukum acara perdata.

\section{E. Kesimpulan.}

Berdasarkan pembahasan di atas, maka dapat ditarik kesimpulan, yakni: Pertama, pengaturan terhadap sita jaminan atas saham yang diberlakukan adalah ketentuan dalam HIR yang memiliki posisi setara dengan undang-undang sebagai

27 Wawancara Peneliti dengan Hakim Pengadilan Negeri Kelas IA Khusus Bandung, Pak Mangapul Girsang, pada tanggal 4 Maret 2020, Pukul 14.00 WIB.

${ }^{28}$ R. Soeparmono, 1997, Masalah Sita Jaminan (CB) dalam Hukum Acara Perdata, Mandar Maju, Bandung, hlm. 7.

${ }^{29}$ M. Rendi Aridhayandi, "Kajian tentang Penerapan Sanksi Pidana terhadap Pelaku yang melakukan Perbuatan Curang dalam Bisinis Dihubungkan dengan Pasal 379a KUHP”, Dialogia Iuridica, (Vol 8 Nomor 2, 2018), hlm. 82. 
hukum positif yang mengatur acara perdata di Indonesia dan merupakan sumber hukum yang sebenar-benarnya. Dengan demikian, secara kaidah hukum acara perdata, pelaksanaan sita jaminan atas saham dapat dilaksanakan atau dapat dimohonkan oleh pihak berperkara sepanjang memenuhi unsur pokok yang telah diatur dalam Pasal 227 HIR sehingga tidak benar apabila Hakim dalam putusannya menjadikan Buku II sebagai dasar hukum, mengingat Buku II bukanlah sebuah sumber hukum atau produk regulasi serta bukanlah sebuah regelende functie mengingat tidak terjadinya kekosongan hukum ketika berbicara mengenai sita jaminan atas objek saham yang telah diatur berdasarkan HIR.

Kedua, terdapat perbedaan mekanisme eksekusi sita jaminan terhadap saham pada Perseroan Tertutup dan Terbuka, dimana tidak terdapat problematika saat eksekusi sita atas saham konvensional (Tertutup) dikarenakan penyitaannya bersifat administratif, dimana sifat saham itu tidak berwujud sehingga lebih memiliki makna yuridis. ${ }^{30}$ Mekanisme saat proses eksekusi, cukup dengan juru sita menyatakan jumlah lembaran saham dan identitas kepemilikannya yang kemudian penetapan sita saham tersebut didaftarkan di Depkumham. Sedangkan, hambatan dalam mekanisme eksekusi sita jaminan saham hanya terjadi pada penyitaan atas saham go public karena saham-saham tersebut berada pada Bursa Efek, yang pada hakikatnya secara yuridis boleh disita tetapi dalam pelaksanaannya sudah diketahui akan sulit dilaksanakan, bagaimana mendaftarkan ke Depkumham karena tidak diketahuinya seri daripada saham tersebut, oleh karena itu penyitaan tersebut menjadi tidak efektif karena kesulitan mengidentifikasi saham yang berada di Bursa Efek. Ketiga, berkaitan dengan mekanisme eksekusi sita jaminan terhadap saham yang tidak diatur dalam HIR menjadikan peraturan itu sendiri menjadi tidak jelas, dan di sisi lain, peraturan diciptakan untuk mencapai kepastian hukum jika melihat kembali pada cita-cita hukum Indonesia. Oleh karena itu, untuk mencapai suatu kepastian hukum diperlukan adanya produk hukum acara perdata nasional dalam sebuah bentuk undang-undang (wet) yang dapat mengakomodir dinamika-dinamika hukum, mengingat bahwa terdapat dualisme hukum pada produk hukum acara perdata saat ini. Jika sudah tercipta dalam suatu produk perundang-undangan, maka akan tercipta kepastian hukum dalam praktik pelaksanaan sita jaminan atas saham dalam rangka penyelesaian sengketa hukum acara perdata.

\section{Daftar Pustaka}

\section{Buku:}

Ibrahim, John, (2013), Teori dan Metodologi Penelitian Hukum Normatif, Malang : Bayumedia Publishing

${ }^{30}$ Wawancara Peneliti dengan Hakim Pengadilan Negeri Kelas IA Khusus Jakarta Selatan, Pak Djoko Indiarto, pada tanggal 7 Maret 2020, pukul 08.00 WIB. 
Indrati, Maria Farida, (2007), Ilmu Perundang-Undangan: Jenis, Fungsi, dan Materi Muatan, Yogyakarta: Kanisius

Kansil, C.S.T dan Christine Kansil, (2005), Hukum Perusahaan Indonesia (Aspek Hukum dalam Ekonomi), Jakarta : PT. Pradnya Paramita

Meliala, Djaja. (2015). Perkembangan Hukum Perdata Tentang Benda dan Hukum Perikatan. Bandung: Nuansa Aulia.

Mertokusumo, Sudikno, (2005), Hukum Acara Perdata, Yogyakarta : Liberty

Sastrawidjaja, Man dan Rai Mantili, (2008), Perseroan Terbatas Menurut Tiga Undang-Undang, Bandung : Alumni,

Soeparmono, R, (1997), Masalah Sita Jaminan (CB) dalam Hukum Acara Perdata, , Bandung : Mandar Maju

Sutantio, Retnowulan dan Iskandar Oeripkartawinata, (2009), Hukum Acara Perdata dalam Teori dan Praktek, Bandung : Mandar Maju,

\section{Jurnal:}

Aridhayandi, Rendi, "Kajian tentang Penerapan Sanksi Pidana terhadap Pelaku yang melakukan Perbuatan Curang dalam Bisinis Dihubungkan dengan Pasal 379a KUHP”, Dialogia Iuridica, Vol 8 No. 2, 2017.

Napitupulu, Tumpal, "Pembatasan Kewenangan Hakim untuk tidak melakukan Sita Jaminan atas Saham Dikaitkan dengan Buku Pedoman Teknis Administrasi dan Teknis Perdata Umum”, Mimbar Justitia, Vol 3 No. 1, 2017.

\section{Peraturan Perundang-undangan}

Undang-Undang Dasar Negara Republik Indonesia Tahun 1945

Undang-Undang Nomor 14 Tahun 1985 Tentang Mahkamah Agung.

Undang-Undang Nomor 12 Tahun 2011 Tentang Pembentukan Peraturan Perundangundangan

Kitab Undang-Undang Hukum Perdata.

Herzien Inlandsch Reglement.

Keputusan Ketua Mahkamah Agung Republik Indonesia Nomor KMA/032/SK/IV/2006 Tentang Buku II Pedoman Teknis Administrasi dan Teknis Peradilan Perdata Umum.

\section{Internet}

Mahendra, Oka, "Harmonisasi Peraturan Perundang-Undangan", http://ditjenpp.kemenkumham.go.id/htn-dan-puu/421-harmonisasi-peraturanperundang-undangan.html, diakses pada 5 Januari 2020.

Online, Primair, "Persamaan Persepsi Penerapan Hukum Rakernas", http://www.primaironline.com/berita/detail.php?catid=Peradilan\&artid=rakernasma-rekomendasikan-persamaan-persepsi-penerapan-hukum, diakses pada 3 Januari 2020. 